\title{
The feed beyond need: mechanisms of the hedonic control of eating
}

\author{
A alimentação além da necessidade: mecanismos do controle hedônico da alimentação \\ Alimentación más allá de la necesidad: mecanismos hedónicos de control de la alimentación
}

Received: 02/06/2022 | Reviewed: 02/12/2022 | Accept: 02/19/2022 | Published: 03/01/2022

\author{
Mayara Matias de Oliveira \\ ORCID: https://orcid.org/0000-0001-5942-5458 \\ Federal University of Pernambuco, Brazil \\ E-mail: mayaramatiasoliveira@gmail.com \\ Elton Gabriel Fernandes de Brito \\ ORCID: https://orcid.org/0000-0003-2428-6851 \\ Federal University of Pernambuco, Brazil \\ E-mail:elton.gabriel@upe.br \\ Keilla Maria Paz e Silva \\ ORCID: https://orcid.org/0000-0001-7246-9519 \\ Medicine College of Olinda, Brazil \\ E-mail: keillampsilva@gmail.com \\ Flávia Regina Gonçalves de Araújo \\ ORCID: https://orcid.org/0000-0001-5484-3570 \\ Medicine College of Olinda, Brazil \\ E-mail: flavia_regina_@hotmail.com \\ Taisy Cinthia Ferro Cavalcante \\ ORCID: https://orcid.org/0000-0002-6498-5158 \\ Federal University of Pernambuco, Brazil \\ E-mail:taisy.cavalcante@upe.br \\ Amanda Alves Marcelino da Silva \\ ORCID: https://orcid.org/0000-0002-5109-3900 \\ Federal University of Pernambuco, Brazil \\ E-mail: amanda.silva@upe.br \\ Sandra Lopes de Souza \\ ORCID: https://orcid.org/0000-0003-4562-6042 \\ Federal University of Pernambuco, Brazil \\ E-mail: sanlopesufpe@gmail.com
}

\begin{abstract}
Eating behaviors arise from a combination of several factors namely, physiological, emotional, social and genetic, including the prevailing state of the environment that the individual has been exposed to from the commencement of development. Several factors are known to affect the control of eating behaviors, distinguishable by the synergism of the homeostatic and hedonic control mechanisms, which are complementary. While undeniably homeostasis is under the control of the hormonal interchange between the intestine and the brain, the desire to eat is focused on the brain reward system, which includes acquisition and addictions and binge eating. In today's world, the easy availability of processed foods, high in sugars and fats, which stimulate the reward areas, can flood the brain with neurotransmitters linked to pleasure and happiness. This often results in an uncontrollable desire to eat, technically termed hedonic hunger. A presentation of an integrated perspective of the mechanisms involved in the control of hedonic eating behavior is given. It is crucial to understand these mechanisms, particularly paying attention to the ways the modern food environment induces excessive consumption and its contributions to the present obesity epidemic.
\end{abstract}

Keywords: Eating behavior; Hedonic consumption; Food addiction; Palatability.

\section{Resumo}

O comportamento alimentar é resultado da interação de fatores fisiológicos, emocionais, sociais, genéticos e até das condições ambientais às quais o indivíduo é exposto desde início do desenvolvimento. Diversos fatores influenciam o controle do comportamento alimentar, no entanto, esse pode ser caracterizado pelo sinergismo de dois mecanismos de controle complementares: homeostático e hedônico. Embora a homeostase seja controlada pelo diálogo hormonais entre o intestino e o cérebro, o desejo de comer está centrado no sistema de recompensa do cérebro, que também está envolvido na aquisição e vícios e compulsão alimentar. O mundo moderno está saturado por alimentos altamente processados, açucarados e gordurosos, que ativam áreas de recompensa, inundando o cérebro com neurotransmissores relacionados ao prazer e felicidade. A consequência disso é a necessidade, muitas vezes incontrolável de comer, conhecida também como fome hedônica. Esta revisão apresenta uma visão integrativa dos mecanismos envolvidos no controle do comportamento alimentar hedônico. O entendimento destes mecanismos torna-se especialmente 
importante para compreender como o ambiente alimentar moderno leva ao consumo excessivo e sua contribuição para a atual epidemia da obesidade.

Palavras-chave: Comportamento alimentar; Consumo hedônico; Adição alimentar; Palatabilidade.

\section{Resumen}

La conducta alimentaria es el resultado de la interacción de factores fisiológicos, emocionales, sociales, genéticos e incluso de las condiciones ambientales a las que está expuesto el individuo desde el inicio del desarrollo. Varios factores influyen en el control de la conducta alimentaria, sin embargo, este se puede caracterizar por el sinergismo de dos mecanismos de control complementarios: homeostático y hedónico. Aunque la homeostasis está controlada por el diálogo hormonal entre el intestino y el cerebro, el deseo de comer se centra en el sistema de recompensa del cerebro, que también está involucrado en la adquisición y adicciones y atracones. El mundo moderno está saturado de alimentos altamente procesados, azucarados y grasos que activan áreas de recompensa, inundando el cerebro con neurotransmisores relacionados con el placer y la felicidad. La consecuencia de esto es la necesidad a menudo incontrolable de comer, también conocida como hambre hedónica. Esta revisión presenta una visión integradora de los mecanismos implicados en el control de la conducta alimentaria hedónica. Comprender estos mecanismos se vuelve especialmente importante para comprender cómo el entorno alimentario moderno conduce al consumo excesivo y su contribución a la actual epidemia de obesidad.

Palabras clave: Comportamiento alimentario; Consumo hedónico; Adicción a la comida; Palatabilidad.

\section{Introduction}

Right through human history, the human body has utilized the adaptive mechanism of eating and consuming calories in response to the depletion of energy stores (Lowe \& Levine, 2005). The primary goal of food-seeking was survival and an effort to ward off starvation (Lowe \& Butryn, 2007). At present, most food is consumed for reasons other than acute energy deprivation (Lowe \& Levine, 2005). Today, there are other reasons that trigger the search for food, mainly for pleasure, and not for calorie acquisition alone (Lowe \& Butryn, 2007). Hence, the crosstalk that occurs between the physiological state and the emotional processes governs the intensity and behavioral intentions that drive the search, desire and motivation for food (Sternson et al., 2013).

Although homeostasis is controlled by hormonal stimuli that dialogue with the intestine and the brain, the act of eating goes beyond maintaining the energy balance (Lowe \& Levine, 2005). Eating behavior is the translation of the adaptive response resulting from the need for the internal environment, which is shaped by stimuli imposed by the external environment 4. The constant availability and frequent consumption of highly palatable foods, adverse experiences in the early stages of development and emotional triggers inherent in the modern routines of life are the catalysts for the mechanisms of hedonic control of eating behavior (Lowe \& Levine, 2005; Rodrigues et al., 2021). This excess of dietary stimuli has contributed to the development of inappropriate eating behaviors and the increase in obesity and physical comorbidities (diabetes, heart disease, etc.) (Lowe \& Levine, 2005; Rodrigues et al., 2021).

Stress-induced eating or 'comfort foods' is an occurrence involving a rise in food consumption when the individual experiences emotional or physical challenges (Hu et al., 2016). Besides, negative urgency (implying an inclination to react spontaneously when feeling negative emotions) has been noted to be related to unsuitable eating behaviors, such as binge eating and the consumption of unhealthy snacks (Mason et al., 2020). The emotional and cognitive features linked to this desire to eat focus on the reward system in the brain, which are also related to addictions (Blanco-Gandia et al., 2020; Brutman et al., 2020). Perspectives, emotions, and food cravings without any energy deficit are the characteristics of the state of hedonic hunger (Lowe \& Butryn, 2007; Takgbajouah \& Buscemi, 2021).

As hedonic hunger is innately reward and emotion-based, it has been observed to have a bearing on an escalation in the responses in different regions of the brain, as implied neural and perceptual reactions to signals of tasty food (Lowe et al., 2009). Several neurocircuits and hormones, identified as the basis of hunger and satiety feelings, also cause changes in the activities occurring in the neural pathways concerned with food, pleasure and reward, and heightened by stimuli (Berridge, 
2009). The involvement, specifically of the dopaminergic, serotonergic, and opioid system has been noted in the motivational and hedonic characteristics of food (Barry et al., 2018; Berridge et al., 2009; Hernandez et al., 2021). From these results, it has emerged that despite eating being possibly among the most fundamental and primitive behaviors of humanity, its complex and continuous evolution cause the neural circuits that control it to remain obscure. In this review, knowledge regarding the neurochemical basis and integrated mechanisms that control hedonic eating behavior, is consolidated, and presented. Clear understanding of the physiological and psychological constituents that influence appetite is crucial to comprehend the pharmacological targets of the present therapies and thereby suggest new objectives and mediating actions that can assist in controlling the strong hedonic effects and coping with life in the modern days obesogenic conditions.

\section{Methodology}

This is a review of a qualitative narrative study, suitable for mapping and discussing knowledge about the hedonic control of eating behavior. This review model is the result of extensive literature, without establishing a rigorously replicable methodology at the level of data reproduction and absolute numbers for specific questions. As it is a bibliographic analysis on the hedonic control of eating behavior and understanding on the subject, articles indexed in the Pubmed database were retrieved.

The indexing terms or descriptors hedonic control of eating behavior, obesity and reward system alone or in combination were used, without defining a time interval. The criterion in the abstract that the text relates to the association of hedonic control of eating behavior, with links to obesity. Excluded articles did not constitute the inclusion criteria included. To analyze the specific production of data identified, specified and/or widely used for data processing, a data analysis was performed.

\section{Results and Discussion}

\subsection{Hypothalamus and the interface between homeostatic and hedonic controls}

For good understanding of the way food can gratify, as well as the methods of the hedonic eating behavior control, the various homeostatic and hedonic sensory mechanisms which govern food regulation and cause it to be a rewarding experience, must be considered. Hedonic regulation is related to the happy or pleasurable feelings derived prior to, during and post the intake of palatable food and has the ability to overrule homeostatic control even when the body has no need of energy (Lutter $\&$ Nestler, 2009). The hypothalamus, above all the other brain regions, shows involvement in this process and plays a vital role as an assimilator of the stimuli and responses linked to the control of food intake (Kenny, 2011; Lutter \& Nestler, 2009).

The arcuate hypothalamic nuclei (ARC), paraventricular (PVN), ventromedial (VMN), dorsomedial (DMH) and lateral hypothalamic areas (LHA) play active roles in food control by releasing orexigenic and anorexigenic neurotransmitters (Sternson et al., 2013). Besides, they influence the food choices, consistency, palatability, learning, smell and the outcomes of hormonal manipulations (Wynne et al.,2005). The arcuate nucleus integrates the peripheral, neural and sensory stimuli (Woods, 2004). Here, the co-expression of the neuropeptide Y (NPY) and protein linked to the agouti gene (AgRP) are observed, both of which induce food intake (Woods, 2004; Wynne et al., 2005). Apart from this, within the ARC the proopium-melanocortin (POMC) and transcript related to cocaine and amphetamine (CART) are also expressed, which induce satiety (Woods, 2004; Wynne et al., 2005). The two neuronal populations present in the arcuate nucleus show sensitivity to gastrointestinal tract signals, through the adipose tissue (energy supplier), and the concentrations of the nutrients in circulation (Woods, 2004) (Berthoud \& Morrison, 2008). Second order neurons are present in the paraventricular, dorsomedial and lateral hypothalamic nuclei (Wynne et al., 2005). These process the data drawn from the arcuate, periphery and other brain regions, to 
make the necessary alterations and establish energy homeostasis (Woods, 2004; Wynne et al., 2005).

Homeostatic control can be affected by stimulation of the hedonic control factors namely, odor, flavor and texture, as well as the lipid content, simple sugars present and visual stimuli of food (Kelley \& Berridge, 2002). Thus, when these factors are present during the process of eating, they activate the Reward System. This can lengthen the duration of a meal by slowing down the homeostatic system responses and permitting more intake of food (Erlanson-Albertsson, 2005). Palatable foods, particularly rich in lipids and carbohydrates, stimulate the hedonic pathways (Erlanson-Albertsson, 2005). The reward system includes the cortico-mesolimbic brain regions, like the nucleus accumbens, ventral striatum, ventral tegmental area, prefrontal cortex, hippocampus and amygdala (Berridge, 2009), which can process the food, in terms of its characteristics like taste, appearance, and texture, thereby providing an incentive of value (Erlanson-Albertsson, 2005).

The route the palatable information takes is complex because it is dependent upon the nutritional (carbohydrate- or fat-rich) and sensitive values of the food (sight, smell, taste, and texture) (Rolls, 2006). Different regions of the brain process the food information that stimulates the sensitive receptors based on the type of sense (Rolls, 2006). Thus, this can take place in the temporal cortex (vision), olfactory bulb (smell), thalamus (texture) and in the nucleus of the solitary tract (taste) (Rolls, 2006). Next, this information will be consolidated by the nucleus and ventral integumentary region (Rolls, 2006). In the amygdala region, the information received from these regions is transformed into emotional stimuli (pleasure); the hippocampus, however, is responsible for recording the 'pleasant experience' in the memory (Kelley \& Berridge, 2002).

\subsection{Learning, liking and wanting: the basis of hedonic food control}

The three principles known to govern the food reward system are, Liking, Wanting and Learning (Berridge, 2009). Even though these motivational principles usually are closely related, different neurophysiological mechanisms orchestrate their actions (Berridge, 2009). 'Learning' is linked to past experiences, long-term memory and compulsion processes (Berridge \& Kringelbach, 2008). Learning can lead to forming and maintaining addictions. Eating behaviors can be altered by a relationship between learning and tasting experiences, connected to pleasure, or otherwise (Yamamoto, 2006). Processing the learning information to transform the food value incentives into neural stimuli is the work mainly done by the amygdala (Baxter \& Murray, 2002). Its interactions with the prefrontal cortex induce the reward stimulus to become a conscious emotional stimulus, and accompanied by the nucleus accumbens, it can direct and modulate the reinforcing operational behaviors (Lalumiere, 2014). A particular type of food, which can be an unconditioned or learned stimulus. This may indicate an 'Outstanding Incentive' period, which implies a conditioned stimulus caused by some motivating element, establishing a compulsive state very like the one induced by crack and cocaine, the drugs of abuse (Berridge \& Kringelbach, 2008). While this mechanism exerts neither a hedonic nor pleasurable impact, it only reveals 'the will' without necessarily relishing the reward (Berridge \& Kringelbach, 2008).

'Liking' is a conscious response linked to cognitive mechanisms, with the principal stimulus being the motivational value of the taste or palatability (Loney et al., 2012). Palatable food stimulates the taste system in a positive manner (Yamamoto, 2008). Thus, the palatable information received by each taste cell moves concertedly to the central nervous system, where the aspects of the cognitive and emotional perceptions will be produced (Yamamoto, 2006). Figure 1 shows a schematic representation of the relationship between the brain areas of the reward system and the behavioral principles of hedonic control of eating behavior. 
Figure 1. Schematic representation of the relationship between the brain areas of the reward system and the behavioral principles of hedonic control of eating behavior.

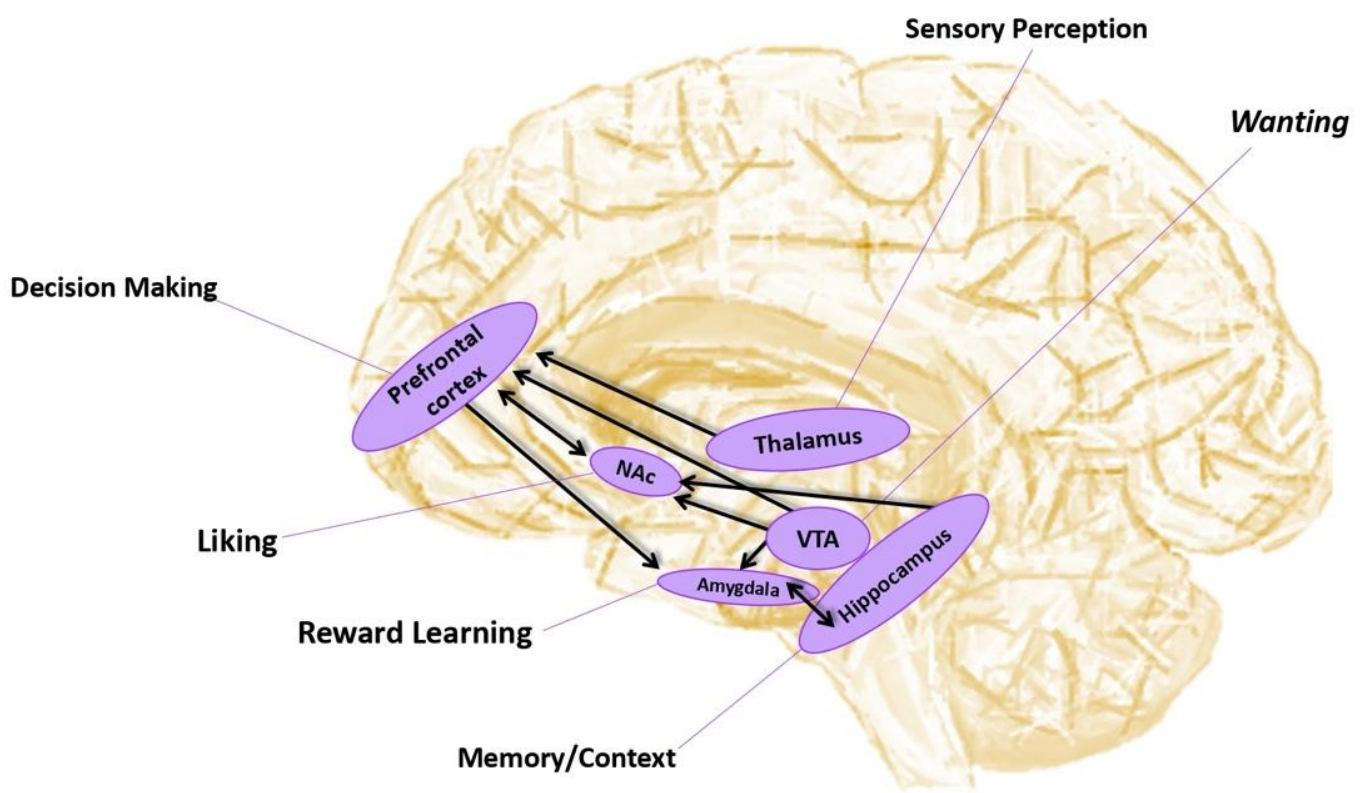

Source: Authors.

In one study the use of the drug D-fenfluramine was reported to reduce hunger, but showed no effect on the assessment of food pleasantness (Blundell \& Hill, 1987). However, while the opioid antagonists were found to reduce the food pleasantness rates they did not affect hunger (Yeomans \& Gray, 2002). This provides evidence for the presence of dissociable systems that mediate the food on homeostatic and hedonic grounds (Yeomans et al., 2004). The opioid and cannabinoid systems are noted to be primarily (although not exclusively) involved in 'Liking', while the dopaminergic and serotonin systems are mostly (although not exclusively) involved in 'Wanting' (Volkow et al., 2011).

\subsection{The neural crosstalk involved in hedonic eating behavior}

The principal determinants of food intake are Taste and Hunger (Lowe \& Levine, 2005). However, many other factors affect food like, stress, physical activity, time of day, social influence and emotional status to name a few (Lowe \& Levine, 2005; Mason et al., 2020). Although these factors control the eating behavior via common neurotransmitter pathways, the degree to which each factor exerts its influence and the diversity of the individual responses continue to remain obscure (Berridge et al., 2009; Lowe \& Levine, 2005; Mason et al., 2020).

For hedonic food control, dopamine acts as the chief neurotransmitter, although other neurotransmitters like serotonin and endogenous opioids also take part in this control (Erlanson-Albertsson, 2005; Rolls, 2006). The dopaminergic cell bodies found in the ventral integumentary area are the principal dopamine producers, which play a role in the control of hedonic food consumption (Kelley \& Berridge, 2002). These neurons possess projections into the nucleus, amygdala, prefrontal cortex and hippocampus (Kelley \& Berridge, 2002). This neural circuit is also involved in the behavioral influences induced by drugs of abuse and natural rewards like food, which trigger dopamine release into the mesolimbic targets (J. Cordeira \& Rios, 2011; Volkow et al., 2011). Other dopaminergic projections also implicated in hedonic eating behaviors include the dorsal striatum (caudate and putamen), cortex (orbitofrontal, cingulate gyrus), limbic regions (hippocampus and amygdala) and lateral 
hypothalamus (Volkow et al., 2011). Glutamatergic afferents to the dopaminergic neurons from those specific regions involved with sensory perception (insula or primary gustatory cortex), homeostasis (hypothalamus), reward (nucleus accumbens), emotion (amygdala and hippocampus), and multimodal actions (orbitofrontal cortex) regulate their activities in response to the rewards and responses conditioned by food (Geisler \& Wise, 2008).

Some research papers have reported lowered dopamine signaling in the striatal regions of individuals with obesity (Geiger et al., 2009; Wang et al., 2001). The reduction in the levels of the D2 receptors and lowered metabolic activity in the orbitofrontal cortex and cingulate gyrus have been connected to obesity and binge eating (Johnson \& Kenny, 2010; Volkow, Wang, Telang, et al., 2008). Besides, the drop in the dopamine activity in the ventral integumentary region induces a rise in the intake of hyperlipidic food in mice (Cordeira et al.,2010).

One of the reasons for the reward deficiency syndrome, expressed as compensatory overfeeding, has been attributed to the hypoactivity of the mesolimbic dopaminergic pathway (Cordeira et al., 2010).

On comparison of the obese persons with thin ones, the former exhibited lower activation of the reward circuitry during actual intake of food (Stice et al., 2008). However, these individuals simultaneously revealed higher activation of the somatosensory cortical regions responsible for processing palatability when food intake was expected (Stice et al., 2008). This implies an imbalance in the reward mechanisms in terms of the food actually consumed and the expected intake. In those circumstances where there is incompatibility between the reward expected and the reward obtained, binge eating is encouraged as a means to achieve the expected degree of reward (Volkow et al., 2011).

A rise in the activity of those areas linked to palatability and lowered dopaminergic activation by actual food intake induces obese individuals to overfeed (Stice et al., 2008). In fact, eating behavior modulates the neuronal mechanisms that regulate the reward / hedonia and energy metabolism. The peripheral signals that control the late signs of homeostatic hunger seem to raise the sensitivity of the limbic areas to food stimulation when they are orexigenic (ghrelin), and reduce the sensitivity to activation when anorectic (leptin and insulin). Deregulation between the homeostatic and hedonic mechanisms may also play a role in overfeeding and development of obesity (Volkow et al., 2011).

Serotonin is another neurotransmitter showing classical involvement in hedonic eating behavior. For around four decades, serotonin has been known to play a part in eating behaviors (Blundell, 1977). Therefore, when selective serotonin reuptake inhibitors (SSRIs), precursors or agonists of serotonergic receptors are administered, they are usually found to inhibit the food consumption by stimulating satiety (a homeostatic phenomenon) (Blundell \& Hill, 1987).

The mechanisms involved in the serotonergic system for the control of hedonic eating behavior are not yet completely understood. This transmitter appears to act on the food reward cascade via modulation of the dopaminergic neurotransmission (Alex \& Pehek, 2007; Chen et al., 2020). This hypothesis is founded on the knowledge that either the stimulation or inhibition of the neurons in the raphe nuclei induces a rise or drop, respectively, in the quantity of dopamine released in the nucleus accumbens (Yoshimoto \& McBride, 1992). Besides, the direct administration of the serotonin into the ventral integumentary region or in the nucleus accumbens causes an escalation in the extracellular dopamine levels (Guan \& McBride, 1989; Parsons \& Justice, 1993).

Seven receptor families are included in this neurotransmitter termed 5HT1R - 5HT7R, subdivided into 14 subtypes. In the homeostatic control of food consumption, the 5-HT1B and 5-HT2C are the principal receptors (O'Dell \& Parsons, 2004). The arcuate nucleus of the hypothalamus contains the NPY / AgRP and POMC / CART neurons, which have the 5-HT1B and 5-HT2C receptors (Heisler et al., 2006). On stimulation, they inhibit the orexigenic pathway and stimulate anorexigenic pathway, thus causing satiety (Heisler et al., 2006; O'Dell \& Parsons, 2004). Synapsis occurs between the serotonergic terminals and the neurons that express the POMC via the 5-HT2C receptor; also, when the 5-HT1B is activated, the neurons that express NPY and AgRP, as well as their inhibitory action on the POMC are inhibited via the GABAergic projections 
(O'Dell \& Parsons, 2004). From these results, it is evident that in the homeostatic control of the energy balance, it is the serotonin that encourages satiety, by stimulation of the anorexigenic neurons, and at the same time, the inhibition of the orexigenics found in the arcuate nucleus of the hypothalamus (Hensler, 2006).

A high density of 5-HT1B receptors occurs within the nucleus accumbens (O'Dell \& Parsons, 2004). The use of the agonist (EMD 386088) of the 5HT-6 receptor was noted to raise the intake of a palatable diet and a standard diet (Pratt, Blackstone, Connolly, \& Skelly, 2009). On activating this receptor, the phosphorylation of dopamine and DARPP-32 was seen to increase via protein kinase A (PKA) (Yun \& Rhim, 2011). Although this is accepted as a classic pharmacological target, the all-pervasive effect of serotonin on eating behaviors, inducing satiety in homeostatic control and palatable food intake in hedonic control, ensures that this neurotransmitter is always present.

As observed, several neural structures that play a role in addictions and compulsive behaviors also show involvement in food reward, as is true for the opioidergic system (Nogueiras et al., 2012). Among the numerous biological actions, the opioid system is well known for its crucial part in the reward system, where it is intricately implicated in encouraging behaviors that are compulsive and addictive, for instance, self-administration of opioid agonists and other drugs of abuse, namely, nicotine and alcohol (Ferenczi et al., 2010). The opioid receptor antagonists are found to attenuate drug use and the desire for palatable foods. From several studies opioid antagonists like naloxone or naltrexone are reported to reduce the consumption of palatable foods; opioid receptor agonists, however, like morphine or enkephalin analogs, increase the consumption of such food types (Holtzman, 1979; Levine et al., 1991; Yeomans \& Gray, 2002). When morphine is administered acutely, apart from other general opioid agonist medications, it reversibly raises the consumption of food, and induces weight gain post naloxone treatment (Ferenczi et al., 2010). Chronic treatment with morphine, however, caused a decrease in the food consumption and body weight (Ferenczi et al., 2010). Overall, the data presented here reveal the presence of a good correlation between the opioid pathways, weight homeostasis and food consumption, in particular of those that are understood as gratifying or palatable. This relationship reveals the significant role played by this neurotransmission system in controlling hedonic eating behaviors, as well as the effect its dysfunction exerts upon the pathophysiology of obesity and other diseases related to any alterations in the body weight. In light of this situation, the N / OFQ system has emerged, which at present is drawing attention for its role in the cognitive and memory processes and dependence on drugs of abuse.

Composed of 17 amino acids, nociceptin / orphanin FQ (N / OFQ) is a peptide, which is different from the other agonists of the opioid receptors because it lacks the tyrosine residue in the $\mathrm{N}$-terminal portion crucial for the agonistic action of the $\mu$ opioid receptors, $\delta$ and $\kappa$ (Reinscheid et al., 1995). Despite the lack of this tyrosine residue, which renders the N / OFQ incapable of binding to the classic opioidergic receptors, it shows a high degree of selectivity for the NOP receptor, which is its own specific receptor (Heinricher, 2003; Reinscheid et al., 1995).

The NOP receptor connects with the inhibitory type G protein. On activation, it slows down the neurotransmission and inhibition of neuronal firing via a reduction in cAMP (Nogueiras et al., 2012; Yun \& Rhim, 2011). Its expression is observed extensively in the central nervous system, in particular in the cerebral cortex, hippocampus, olfactory nucleus, amygdala, thalamic nuclei, besides the noradrenergic and serotonergic nuclei (locus coeruleus and raphe dorsal, respectively) (Mollereau \& Mouledous, 2000). One of the principal features of the N / OFQ neurotransmission system is that the NOP receptor, as well as the molecule itself ( $\mathrm{N} / \mathrm{OFQ}$ ), express themselves in the limbic system in the brain (Mollereau \& Mouledous, 2000). This co-expression emphasizes the premise that the N / OFQ system has some bearing on the modulating behaviors that the limbic system coordinates, including the emotions, reward and regulation of the hypothalamo-pituitaryadrenocortical (HPA) axis (Darland et al., 1998).

There is evidence to show that the N/ OFQ system participates in controlling food consumption in rodents by inducing an orexigenic influence (Polidori et al., 2000; Witkin et al., 2014). In rats, when the N / OFQ was administered 
intracerebroventricularly it was able to trigger anescalation in the food intake in these animals (Polidori et al., 2000).

\subsection{Obesity and hedonic hunger}

Several distinguishing features of the built urban environment which minimize the necessity for expending energy and promote the consumption of ultra-processed, sugar-loaded food, play a role in the global rise of widespread obesity (Handy et al., 2002). The combined effect of the environmental and behavioral factors along with the easy consumption and low energy expenditure have brought about the obesogenic environment mentioned earlier [Figure 2] (Meldrum et al., 2017). Over the last three decades, across the globe, there has been tripling in obesity, making it a global epidemic, and exerting a negative effect across all age groups and socioeconomic strata (Rocha et al., 2019; Samaras et al., 2019).

Figure 2. Diversity of factors involved in hedonic hunger.

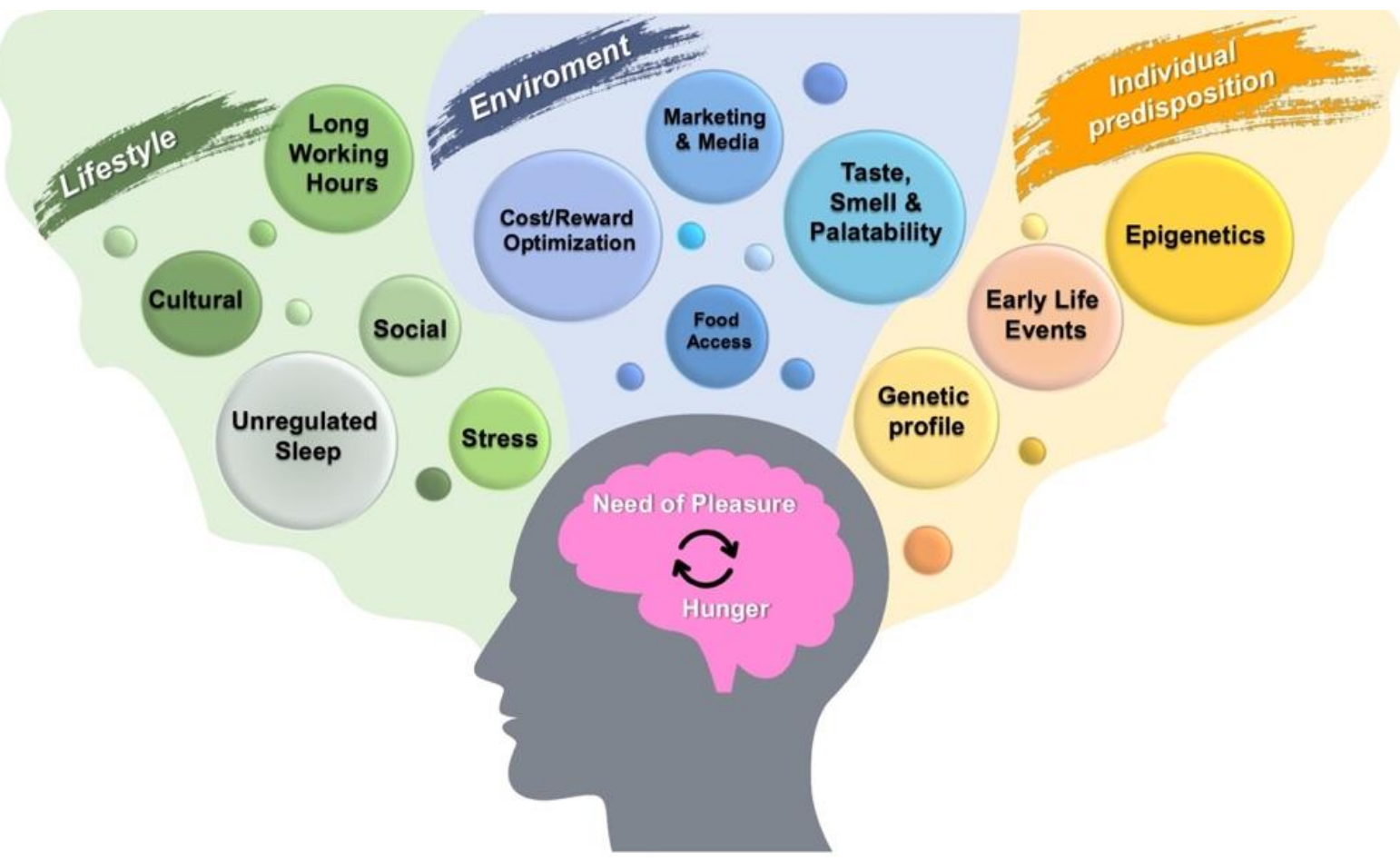

Source: Authors.

Therefore, the impact that modern life has upon the homeostasis of body composition, for example the high cognitive mental work, stress, and alterations in sleep patterns, besides other factors, must be included in this context (Tremblay, 2018). This complexity excludes the simple reductionist approach using very poor body mass loss treatments for obesity (Samaras et al., 2019; Tremblay, 2018).

It was Lowe \& Butryn who first proposed Hedonic Hunger, to refer to the impulse and craving for the intake of food for pleasure, despite the lack of caloric needs (Lowe \& Butryn, 2007; Lowe \& Levine, 2005). This notion reiterates the resemblance between overfeeding and drug abuse, as both actions stimulate the identical mechanism in the reward system. Persons addicted to drugs use these substances as a form of self-medication to escalate or impede the hypofunctional reward system (Volkow et al., 2011). Overfeeding involves the same mechanism (Volkow et al., 2011).

Using imaging studies, four main brain circuits have been identified in the neurobiology of drug abuse, addiction and obesity, as listed: 1) reward / salience; 2) motivation; 3) learning / conditioning; 4) inhibitory control / emotional regulation / executive function (Volkow et al., 2008). A model was proposed, showing the similarity between obesity and vicious behavior. 
It was posited that when the individual was exposed to the reinforcer or conditioned indicators of reinforcement, the expected gratification outcomes were gained by overactivation of the reward system, with a corresponding reduction in the activity of the cognitive control circuit (Volkow et al., 2011). This subscribes to the ineffectiveness of inhibiting the pursuit for and intake of the drug or food, despite the efforts to do this.

Evidence supporting the fact that obesity is linked to cognitive dysfunction and dysregulation in executive functions, attention and memory is now available (Mason et al., 2020; Volkow et al., 2011). Other risk factors for obesity include impulsivity, attention deficit and hyperactivity (Davis, 2009). Moreover, as obesity is a chronic and non-transmissible disease, it can damage almost every single organ system, as related comorbidities, and even mortality can result (Unamuno et al., 2018).

\section{Final Considerations}

Neurobiological research provides support for a better understanding of the methods of controlling hedonic eating behavior and investigates the rationale that drives the habits of food intake. This persistent quest to interpret the mechanisms that govern eating behavior prompts the creation of compounds that act centrally and can be guided to the principal constituents of the neurocircuits involved. Hence, these studies form the basic material to facilitate enhancement of the present treatment and the establishment of more modern treatments, with less side effects.

In several studies, the results reveal similarities in the reward processes of the brain for both obesity and substance abuse disorders. However, focus on the similarities does not detract from the significant differences that exist between obesity and drug addiction. The growing interest in perceiving obesity as a brain disease also emphasizes the thrust of the public health measures in the present obesogenic food environment. These two casuistic lines meet at the point where the development of obesity is responsible for the present global epidemic of obesity and the rise in nutrition-related chronic diseases. In view of this, it is expected that further studies on this subject will be carried out in order to expand the understanding and, thus, outline and promote therapeutic strategies and effective interventions against obesity and the current obesogenic environment.

\section{References}

Alex, K. D., \& Pehek, E. A. (2007). Pharmacologic mechanisms of serotonergic regulation of dopamine neurotransmission. Pharmacol Ther, 113(2), 296-320. 10.1016/j.pharmthera.2006.08.004

Barry, R. L., Byun, N. E., Williams, J. M., Siuta, M. A., Tantawy, M. N., Speed, N. K., \& Avison, M. J. (2018). Brief exposure to obesogenic diet disrupts brain dopamine networks. PLoS One, 13(4), e0191299. 10.1371/journal.pone.0191299

Baxter, M. G., \& Murray, E. A. (2002). The amygdala and reward. Nat Rev Neurosci, 3(7), 563-573. 10.1038/nrn875

Berridge, K. C. (2009). 'Liking' and 'wanting' food rewards: brain substrates and roles in eating disorders. Physiol Behav, 97(5), 537-550. 10.1016/j.physbeh.2009.02.044

Berridge, K. C., \& Kringelbach, M. L. (2008). Affective neuroscience of pleasure: reward in humans and animals. Psychopharmacology (Berl), 199(3), 457480. $10.1007 / \mathrm{s} 00213-008-1099-6$

Berridge, K. C., Robinson, T. E., \& Aldridge, J. W. (2009). Dissecting components of reward: 'liking', 'wanting', and learning. Curr Opin Pharmacol, 9(1), 6573. 10.1016/j.coph.2008.12.014

Berthoud, H. R., \& Morrison, C. (2008). The brain, appetite, and obesity. Annu Rev Psychol, 59, 55-92. 10.1146/annurev.psych.59.103006.093551

Blanco-Gandia, M. C., Minarro, J., \& Rodriguez-Arias, M. (2020). Common Neural Mechanisms of Palatable Food Intake and Drug Abuse: Knowledge Obtained with Animal Models. Curr Pharm Des, 26(20), 2372-2384. 10.2174/1381612826666200213123608

Blundell, J. E. (1977). Is there a role for serotonin (5-hydroxytryptamine) in feeding? Int J Obes, 1(1), 15-42. Retrieved from https://www.ncbi.nlm.nih.gov/pubmed/361584

Blundell, J. E., \& Hill, A. J. (1987). Serotoninergic modulation of the pattern of eating and the profile of hunger-satiety in humans. Int J Obes, 11 Suppl 3, 141-155. Retrieved from https://www.ncbi.nlm.nih.gov/pubmed/3440687 
Brutman, J., Davis, J. F., \& Sirohi, S. (2020). Behavioral and Neurobiological Consequences of Hedonic Feeding on Alcohol Drinking. Curr Pharm Des, 26(20), 2309-2315. 10.2174/1381612826666200206092231

Chen, L., Lu, Y. P., Chen, H. Y., Huang, S. N., Guo, Y. R., Zhang, J. Y., \& Yu, C. X. (2020). Ventral tegmental area GABAergic neurons induce anxiety-like behaviors and promote palatable food intake. Neuropharmacology, 173, 108114. 10.1016/j.neuropharm.2020.108114

Cordeira, J., \& Rios, M. (2011). Weighing in the role of BDNF in the central control of eating behavior. Mol Neurobiol, 44(3), 441-448. 10.1007/s12035-011$8212-2$

Cordeira, J. W., Frank, L., Sena-Esteves, M., Pothos, E. N., \& Rios, M. (2010). Brain-derived neurotrophic factor regulates hedonic feeding by acting on the mesolimbic dopamine system. J Neurosci, 30(7), 2533-2541. 10.1523/JNEUROSCI.5768-09.2010

Darland, T., Heinricher, M. M., \& Grandy, D. K. (1998). Orphanin FQ/nociceptin: a role in pain and analgesia, but so much more. Trends Neurosci, 21(5), 215-221. 10.1016/s0166-2236(97)01204-6

Davis, C. (2009). Psychobiological traits in the risk profile for overeating and weight gain. Int J Obes (Lond), 33 Suppl 2, S49-53. 10.1038/ijo.2009.72

Erlanson-Albertsson, C. (2005). How palatable food disrupts appetite regulation. Basic Clin Pharmacol Toxicol, 97(2), 61-73. 10.1111/j.17427843.2005.pto_179.x

Ferenczi, S., Nunez, C., Pinter-Kubler, B., Foldes, A., Martin, F., Markus, V. L., \& Kovacs, K. J. (2010). Changes in metabolic-related variables during chronic morphine treatment. Neurochem Int, 57(3), 323-330. 10.1016/j.neuint.2010.06.011

Geiger, B. M., Haburcak, M., Avena, N. M., Moyer, M. C., Hoebel, B. G., \& Pothos, E. N. (2009). Deficits of mesolimbic dopamine neurotransmission in rat dietary obesity. Neuroscience, 159(4), 1193-1199. 10.1016/j.neuroscience.2009.02.007

Geisler, S., \& Wise, R. A. (2008). Functional implications of glutamatergic projections to the ventral tegmental area. Rev Neurosci, 19(4-5), 227-244. 10.1515/revneuro.2008.19.4-5.227

Guan, X. M., \& McBride, W. J. (1989). Serotonin microinfusion into the ventral tegmental area increases accumbens dopamine release. Brain Res Bull, 23(6), 541-547. 10.1016/0361-9230(89)90198-6

Handy, S. L., Boarnet, M. G., Ewing, R., \& Killingsworth, R. E. (2002). How the built environment affects physical activity: views from urban planning. Am J Prev Med, 23(2 Suppl), 64-73. 10.1016/s0749-3797(02)00475-0

Heinricher, M. M. (2003). Orphanin FQ/nociceptin: from neural circuitry to behavior. Life Sci, 73(6), 813-822. 10.1016/s0024-3205(03)00412-0

Heisler, L. K., Jobst, E. E., Sutton, G. M., Zhou, L., Borok, E., Thornton-Jones, Z., \& Cowley, M. A. (2006). Serotonin reciprocally regulates melanocortin neurons to modulate food intake. Neuron, 51(2), 239-249. 10.1016/j.neuron.2006.06.004

Hensler, J. G. (2006). Serotonergic modulation of the limbic system. Neurosci Biobehav Rev, 30(2), 203-214. 10.1016/j.neubiorev.2005.06.007

Hernandez, J., Perez, L., Soto, R., Le, N., Gastelum, C., \& Wagner, E. J. (2021). Nociceptin/orphanin FQ neurons in the Arcuate Nucleus and Ventral Tegmental Area Act via Nociceptin Opioid Peptide Receptor Signaling to Inhibit Proopiomelanocortin and A10 Dopamine Neurons and Thereby Modulate Ingestion of Palatable Food. Physiol Behav, 228, 113183. 10.1016/j.physbeh.2020.113183

Holtzman, S. G. (1979). Suppression of appetitive behavior in the rat by naloxone: lack of effect of prior morphine dependence. Life Sci, 24(3), 219-226. $10.1016 / 0024-3205(79) 90222-4$

Hu, M. H., Bashir, Z., Li, X. F., \& O'Byrne, K. T. (2016). Posterodorsal Medial Amygdala Mediates Tail-Pinch Induced Food Intake in Female Rats. $J$ Neuroendocrinol, 28(5). 10.1111/jne.12390

Johnson, P. M., \& Kenny, P. J. (2010). Dopamine D2 receptors in addiction-like reward dysfunction and compulsive eating in obese rats. Nat Neurosci, 13(5), 635-641. 10.1038/nn.2519

Kelley, A. E., \& Berridge, K. C. (2002). The neuroscience of natural rewards: relevance to addictive drugs. J Neurosci, 22(9), 3306-3311. 20026361

Kenny, P. J. (2011). Reward mechanisms in obesity: new insights and future directions. Neuron, 69(4), 664-679. 10.1016/j.neuron.2011.02.016

Lalumiere, R. T. (2014). Optogenetic dissection of amygdala functioning. Front Behav Neurosci, 8, 107. 10.3389/fnbeh.2014.00107

Levine, A. S., Grace, M., \& Billington, C. J. (1991). Beta-funaltrexamine (beta-FNA) decreases deprivation and opioid-induced feeding. Brain Res, 562(2), 281-284. 10.1016/0006-8993(91)90632-6

Loney, G. C., Blonde, G. D., Eckel, L. A., \& Spector, A. C. (2012). Determinants of taste preference and acceptability: quality versus hedonics. J Neurosci, 32(29), 10086-10092. 10.1523/JNEUROSCI.6036-11.2012

Lowe, M. R., \& Butryn, M. L. (2007). Hedonic hunger: a new dimension of appetite? Physiol Behav, 91(4), 432-439. 10.1016/j.physbeh.2007.04.006

Lowe, M. R., Butryn, M. L., Didie, E. R., Annunziato, R. A., Thomas, J. G., Crerand, C. E., \& Halford, J. (2009). The Power of Food Scale. A new measure of the psychological influence of the food environment. Appetite, 53(1), 114-118. 10.1016/j.appet.2009.05.016

Lowe, M. R., \& Levine, A. S. (2005). Eating motives and the controversy over dieting: eating less than needed versus less than wanted. Obes Res, 13(5), 797806. $10.1038 /$ oby. 2005.90

Lutter, M., \& Nestler, E. J. (2009). Homeostatic and hedonic signals interact in the regulation of food intake. J Nutr, 139(3), 629-632. 10.3945/jn.108.097618 
Mason, T. B., Dunton, G. F., Gearhardt, A. N., \& Leventhal, A. M. (2020). Emotional disorder symptoms, anhedonia, and negative urgency as predictors of hedonic hunger in adolescents. Eat Behav, 36, 101343. 10.1016/j.eatbeh.2019.101343

Meldrum, D. R., Morris, M. A., \& Gambone, J. C. (2017). Obesity pandemic: causes, consequences, and solutions-but do we have the will? Fertil Steril, 107(4), 833-839. 10.1016/j.fertnstert.2017.02.104

Mollereau, C., \& Mouledous, L. (2000). Tissue distribution of the opioid receptor-like (ORL1) receptor. Peptides, 21(7), 907-917. 10.1016/s01969781(00)00227-8

Nogueiras, R., Romero-Pico, A., Vazquez, M. J., Novelle, M. G., Lopez, M., \& Dieguez, C. (2012). The opioid system and food intake: homeostatic and hedonic mechanisms. Obes Facts, 5(2), 196-207. 10.1159/000338163

O'Dell, L. E., \& Parsons, L. H. (2004). Serotonin1B receptors in the ventral tegmental area modulate cocaine-induced increases in nucleus accumbens dopamine levels. J Pharmacol Exp Ther, 311(2), 711-719. 10.1124/jpet.104.069278

Parsons, L. H., \& Justice, J. B., Jr. (1993). Serotonin and dopamine sensitization in the nucleus accumbens, ventral tegmental area, and dorsal raphe nucleus following repeated cocaine administration. J Neurochem, 61(5), 1611-1619. 10.1111/j.1471-4159.1993.tb09794.x

Polidori, C., de Caro, G., \& Massi, M. (2000). The hyperphagic effect of nociceptin/orphanin FQ in rats. Peptides, 21(7), 1051-1062. 10.1016/s01969781(00)00243-6

Pratt, W. E., Blackstone, K., Connolly, M. E., \& Skelly, M. J. (2009). Selective serotonin receptor stimulation of the medial nucleus accumbens causes differential effects on food intake and locomotion. Behav Neurosci, 123(5), 1046-1057. 10.1037/a0016882

Reinscheid, R. K., Nothacker, H. P., Bourson, A., Ardati, A., Henningsen, R. A., Bunzow, J. R., \& Civelli, O. (1995). Orphanin FQ: a neuropeptide that activates an opioidlike G protein-coupled receptor. Science, 270(5237), 792-794. 10.1126/science.270.5237.792

Rocha, V. D. S., Claudio, E. R. G., da Silva, V. L., Cordeiro, J. P., Domingos, L. F., da Cunha, M. R. H., \& Leopoldo, A. S. (2019). High-Fat Diet-Induced Obesity Model Does Not Promote Endothelial Dysfunction via Increasing Leptin/Akt/eNOS Signaling. Front Physiol, 10, 268. 10.3389/fphys.2019.00268

Rodrigues, G. D., Fiorelli, E. M., Furlan, L., Montano, N., \& Tobaldini, E. (2021). Obesity and sleep disturbances: The "chicken or the egg" question. Eur J Intern Med, 92, 11-16. 10.1016/j.ejim.2021.04.017

Rolls, E. T. (2006). Brain mechanisms underlying flavour and appetite. Philos Trans R Soc Lond B Biol Sci, 361(1471), 1123-1136. 10.1098/rstb.2006.1852

Samaras, K., Tevaearai, H., Goldman, M., le Coutre, J., \& Holly, J. M. P. (2019). Editorial: With Obesity Becoming the New Normal, What Should We Do? Front Endocrinol (Lausanne), 10, 250. 10.3389/fendo.2019.00250

Sternson, S. M., Nicholas Betley, J., \& Cao, Z. F. (2013). Neural circuits and motivational processes for hunger. Curr Opin Neurobiol, 23(3), 353-360. 10.1016/j.conb.2013.04.006

Stice, E., Spoor, S., Bohon, C., \& Small, D. M. (2008). Relation between obesity and blunted striatal response to food is moderated by TaqIA A1 allele. Science, 322(5900), 449-452. 10.1126/science.1161550

Takgbajouah, M., \& Buscemi, J. (2021). Applying the developmental model of use disorders to hedonic hunger: a narrative review. J Addict Dis, 1-9. 10.1080/10550887.2021.1926881

Tremblay, A. (2018). Obesity Management: What Should We Do If Fat Gain Is Necessary to Maintain Body Homeostasis in a Modern World? Front Endocrinol (Lausanne), 9, 285. 10.3389/fendo.2018.00285

Unamuno, X., Gomez-Ambrosi, J., Rodriguez, A., Becerril, S., Fruhbeck, G., \& Catalan, V. (2018). Adipokine dysregulation and adipose tissue inflammation in human obesity. Eur J Clin Invest, 48(9), e12997. 10.1111/eci.12997

Volkow, N. D., Wang, G. J., \& Baler, R. D. (2011). Reward, dopamine and the control of food intake: implications for obesity. Trends Cogn Sci, $15(1)$, 37-46. 10.1016/j.tics.2010.11.001

Volkow, N. D., Wang, G. J., Fowler, J. S., \& Telang, F. (2008). Overlapping neuronal circuits in addiction and obesity: evidence of systems pathology. Philos Trans $R$ Soc Lond B Biol Sci, 363(1507), 3191-3200. 10.1098/rstb.2008.0107

Volkow, N. D., Wang, G. J., Telang, F., Fowler, J. S., Thanos, P. K., Logan, J., \& Pradhan, K. (2008). Low dopamine striatal D2 receptors are associated with prefrontal metabolism in obese subjects: possible contributing factors. Neuroimage, 42(4), 1537-1543. 10.1016/j.neuroimage.2008.06.002

Wang, G. J., Volkow, N. D., Logan, J., Pappas, N. R., Wong, C. T., Zhu, W., \& Fowler, J. S. (2001). Brain dopamine and obesity. Lancet, 357(9253), 354357. 10.1016/s0140-6736(00)03643-6

Witkin, J. M., Statnick, M. A., Rorick-Kehn, L. M., Pintar, J. E., Ansonoff, M., Chen, Y., \& Ciccocioppo, R. (2014). The biology of Nociceptin/Orphanin FQ (N/OFQ) related to obesity, stress, anxiety, mood, and drug dependence. Pharmacol Ther, 141(3), 283-299. 10.1016/j.pharmthera.2013.10.011

Woods, S. C. (2004). Gastrointestinal satiety signals I. An overview of gastrointestinal signals that influence food intake. Am J Physiol Gastrointest Liver Physiol, 286(1), G7-13. 10.1152/ajpgi.00448.2003

Wynne, K., Stanley, S., McGowan, B., \& Bloom, S. (2005). Appetite control. J Endocrinol, 184(2), 291-318. 10.1677/joe.1.05866

Yamamoto, T. (2006). Neural substrates for the processing of cognitive and affective aspects of taste in the brain. Arch Histol Cytol, 69(4), 243-255. 10.1679/aohc.69.243 
Research, Society and Development, v. 11, n. 3, e41911326626, 2022

(CC BY 4.0) | ISSN 2525-3409 | DOI: http://dx.doi.org/10.33448/rsd-v11i3.26626

Yamamoto, T. (2008). Central mechanisms of roles of taste in reward and eating. Acta Physiol Hung, 95(2), 165-186. 10.1556/APhysiol.95.2008.2.2

Yeomans, M. R., Blundell, J. E., \& Leshem, M. (2004). Palatability: response to nutritional need or need-free stimulation of appetite? Br J Nutr, 92 Suppl 1 , S3-14. 10.1079/bjn20041134

Yeomans, M. R., \& Gray, R. W. (2002). Opioid peptides and the control of human ingestive behaviour. Neurosci Biobehav Rev, 26(6), 713-728. $10.1016 / \mathrm{s} 0149-7634(02) 00041-6$

Yoshimoto, K., \& McBride, W. J. (1992). Regulation of nucleus accumbens dopamine release by the dorsal raphe nucleus in the rat. Neurochem Res, 17(5), 401-407. 10.1007/BF00969884

Yun, H. M., \& Rhim, H. (2011). The serotonin-6 receptor as a novel therapeutic target. Exp Neurobiol, 20(4), 159-168. 10.5607/en.2011.20.4.159 